5. Levchenko A.G. Features of the manifestation of mastitis in cows at farms with different technologies and the development of comprehensive preventive and curative measures: dis. for the sciences. Degree Candidate vet Sciences: special 16.00.03 "Veterinary Microbiology, Epizootology, Infectious Diseases and Immunology" / A.G.Levchenko. - Kyiv, 2015. - 20 p. (in Ukrainian).

6. Kraevskii AI Bacterial mastitis in cows: monograph / AI Kraevskii, MV Rublenko, GPP Dyulger. - Sumy, 2014. - C.12 - 29. (in Ukrainian).

7. Methods of immunological research in laboratories of veterinary medicine / V.M.Ivchenko, M.S. Pavlenko, A.I. Gorbatyuk and others. - Belaya Tserkov, 2003. - 79 p. (in Ukrainian).

8. Kazmirchuk V.Ye. Clinical immunology and allergology / V. Ya. Kazmirchuk, L.V. Kovalchuk. - Vinnytsya: New Book, 2006. - P. 267-275. (in Ukrainian).

9. Slonim AA Determination of bactericidal activity of serum of blood and lymph / A. Slonim, Yu. D. Tolcheev // Laboratory case. -1989 - No. 7. - P.65 - 66. (in Ukrainian).

10. Chumachenko V.E. Methodical recommendations on determination of natural resistance in agricultural animals for veterinary specialists / V.E. Chumachenko, V.S. Sichkar, Yu.V. Olenich. - K.: USCA, 1992. - P. 36 - 47. (in Ukrainian).

Рецензент - С. І. Улизько, к. вет. н., доцент, Одеський ДАУ.

УДК 577.1:612.015

doi: 10.36359/scivp.2019-20-2.13

\title{
МОРФОЛОГІЧНІ ПОКАЗНИКИ КРОВІ ЩУРІВ ЗА УМОВ ОКСИДАЦІЙНОГО СТРЕСУ ТА ЗА ДІЇ КОРМОВОЇ ДОБАВКИ «БУТАСЕЛМЕВІТ-ПЛЮС»
}

\author{
T. B. Мартишук ${ }^{1}$, аспірант, \\ Б. В. Гутийㄹ, д-р вет. наук, професор \\ ${ }^{1}$ Інститут біології тварин НААН, \\ вул. В. Стуса, 38, 79000, м. Львів, Україна \\ ${ }^{2}$ Львівський національний університет ветеринарної медицини та біотехнологій \\ імені С.3. Гжицького, \\ вул. Пекарська, 50, м. Львів, 79010, Україна
}

\begin{abstract}
Вільнорадикальне окиснення відіграє надзвичайно важливу роль у розвитку багатьох патологічних прочесів. Отруєння експериментальних тварин тетрахлорметаном за морфологічною картиною та біохімічними змінами близьке до гострих уражень печінки різної етіології у людини та тварин. Саме тому у нашій роботі використано класичну модель ушкодження субклітинних мембран гепатоиитів та розвитку оксидаційного стресу на основі застосування тетрахлорметану. Метою роботи було вивчити морфологічні показники крові щурів за умов оксидачійного стресу та за дї кормової добавки «Бутаселмевіт-плюс». Дослідження проводили на білих статевозрілих молодих щурах-самиях лінії Вістар, масою тіла 180-200 2, яких утримували на стандартному раціоні інститутського віварію Державного науково-дослідного контрольного інституту ветеринарних препаратів та кормових добавок. Тварин було поділено на три групи по 20 тварин у кожній: 1-ша група (К)
\end{abstract}


інтактні тварини; 2-га група (Д 1 - щурі, ураженні тетрахлорметаном; 3-тя група (Д2) щурі, ураженні тетрахлорметаном та яким застосовували кормову добавку "Бутаселмевітплюс”. Експериментальну інтоксикаиію у тварин проводили шляхом дворазового (через 48 год) внутрішлункового введення тетрахлорметану в дозі 0,1 мл на 100 г маси тіла щура у вигляді 50 \% олійного розчину. Дослідній групі Д2 за експериментального токсикозу впродовж 30 діб згодовували кормову добавку “Бутаселмевіт-плюс" в дозі 0,1 г на 100 г маси тіла разом із кормом.

Встановлено, що за умов інтоксикащії тетрахлорметаном у щурів порушується гемопоетична функиія кісткового мозку, шоо проявляється зменшенням кількості еритроцитів на 26,5\%, вмісту гемоглобіну на 8,7\%, концентрації гемоглобіну в еритрочиті на 18,9\%, збільшенням маси гемоглобіну в еритроциті на 24,1 \%, об'єму еритроиита на 53,9 \%. При застосуванні кормової добавки «Бутаселмевіт-плюс» щурам, за умов оксидаційного стресу протягом досліджень, у крові наступає нормалізачія активності гематологічних показників, а саме на 25 і 30-ту доби в межсах фізіологічних величин були показники кількості еритроцитів, вмісту гемоглобіну, кількості лейкоцитів та індекси червоної крові порівняно з контролем, що вказує на відновлення гемопоетичної функиії кісткового мозку.

Ключові слова: ОКСИДАЦИЙНИЙ СТРЕС, ЩУРИ, БУТАСЕЛМЕВІТ-ПЛЮС, КРОВ, РОЗТОРОПША ПЛЯМИСТА.

Хімічні сполуки відносяться до постійно діючих на організм тварин факторів навколишнього середовища. Між зовнішнім хімічним оточенням і хімічним складом організму існує певна рівновага, порушення якої приводить до зрушення гомеостазу. В останні десятиріччя у світі формується токсична ситуація, яка обумовлена інтенсивним впровадженням хімічних речовин у промисловість, сільське господарство, гуманну i ветеринарну медицину та зростанням числа гострих та хронічних отруєнь [1-3].

Останніми роками встановлено роль у патогенезі захворювань печінки процесів активації вільнорадикального окиснення ліпідів плазматичних i внутрішньоклітинних мембран гепатоцитів на тлі виснаження захисних протирадикальних систем [4, 5]. I3 літературних джерел відомо, що надлишкове накопичення продуктів перекисного окиснення ліпідів викликає набряк мітохондрій, роз'єднання процесів дихання та окисного фосфорилювання, ушкодження сульфгідрильних груп тіолових ензимів [5-8]. Фактори, що викликають оксидативний стрес - порушення окисно-відновної рівноваги в бік окиснення i утворення вторинних вільних радикалів. До патологічних порушень гомеостазу, які призводять до оксидаційного стресу, зокрема, відносять: зміна гомеостазу у результаті дії патологічних чинників; зміна гомеостазу у результаті порушення генетичної інформації; дефект регулюючої системи або органу-мішені $[9,10]$. За дії патологічного чинника проходить зміна інтенсивності перекисного окиснення ліпідів, накопичення в крові концентрації продуктів вільнорадикального окиснення та активних форм кисню, зниження буферної ємності крові відносно підтримування оптимальних параметрів інтенсивності вільнорадикальних реакцій $[11,12]$.

Розробка методів інтегральної корекції оксидаційного стану в організмі тварин за дії різних чинників ризику $\epsilon$ важливим фактором у процесі створення біобезпечних та високоефективних препаратів парентерального та перорального призначення. Для підвищення адаптаційної здатності й імунобіологічної реактивності організму, посилення протеїнсинтезувальної та ензимної функції у тварин в останні роки з успіхом використовують нові комплексні препарати [13-15]. Окремими авторами встановлено стимулювальний вплив розторопші плямистої, вітамінів, Селену та бутафосфану на активність антиоксидантної та гепатопротекторної дії у тварин $[16,17]$. Однак комплексне застосування вказаних препаратів на функцію печінки та гематологічні показники на даний час у науковій літературі висвітлене недостатньо. 
Саме тому, метою нашої роботи було вивчити морфологічні показники крові щурів за умов оксидаційного стресу та за дії кормової добавки «Бутаселмевіт-плюс».

Матеріали і методи. Дослідження проводили на білих статево-зрілих молодих щурахсамцях лінії Вістар масою тіла 180-200 г, яких утримували на стандартному раціоні віварію Державного науково-дослідного контрольного інституту ветеринарних препаратів та кормових добавок. Протягом усього експерименту щурів утримували на збалансованому раціоні, що містив усі необхідні компоненти, питну воду тварини отримували без обмежень із скляних поїлок, об'ємом 0,2 літра.

Тварин було поділено на три групи по 20 тварин у кожній: 1-ша група (К) інтактні тварини; 2-га група (Д1) - щурі, ураженні тетрахлорметаном; 3-тя група (Д2) - щурі, ураженні тетрахлорметаном та яким застосовували кормову добавку "Бутаселмевіт-плюс". Експериментальну інтоксикацію у тварин проводили за методикою, описаною О. Ю. Журавльовим та В.М. Гунчаком, шляхом дворазового (через 48 год) внутрішньолункового введення тетрахлорметану в дозі 0,1 мл на 100 г маси тіла щура у вигляді 50 \% олійного розчину. Дослідній групі Д2 за експериментального токсикозу впродовж 30 діб згодовували кормову добавку “Бутаселмевіт-плюс” в дозі 0,1 г на 100 г маси тіла разом із кормом.

Кров для біохімічних досліджень забирали під ефірним наркозом з яремної вени на п’яту, десяту та двадцяту, двадцять п’яту і тридцяту доби експерименту.

Кількість еритроцитів і лейкоцитів підраховували на сітці Горяєва лічильної камери за загальновизнаною методикою. Рівень гемоглобіну крові визначали ціангемоглобіновим методом $з$ використанням ФЕК-М за методом Г. В. Дервіза і А. Г. Воробйова. Величину гематокриту визначали центрифугуванням крові у мікропіпетках за 3000 об/хв. За величинами показників кількості еритроцитів, рівня гемоглобіну крові i величини гематокриту, за відповідними формулами, шляхом математичних розрахунків, вираховували такі величини індексів червоної крові: середній об'єм одного еритроцита (MCV), середня маса гемоглобіну в еритроциті (MCH), середня концентрація гемоглобіну в еритроциті (МCHC) [18].

Аналіз результатів досліджень проводили за допомогою пакету програм Statistica 6.0. Вірогідність різниць оцінювали за t-критерієм Стьюдента. Результати вважали вірогідними при $\mathrm{P} \leq 0,05$.

Результати й обговорення. При експериментальному отруєнні тетрахлорметаном встановлено зниження кількості еритроцитів у крові дослідної групи Д 1 вже починаючи з 5-ої доби досліду, де відповідно вона знизилася на 12,2 \%. На 10- і 20-ту доби досліду кількість еритроцитів у крові першої дослідної групи була найнижчою, де відносно контрольної групи вона знизилася відповідно на 22,9 і 26,5% (табл. 1).

Кількість еритроцитів у крові щурів за умов отрусння тетрахлорметаном

Табличя 1

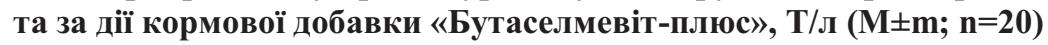

\begin{tabular}{|l|c|c|c|}
\hline \multirow{2}{*}{ Доба досліджень } & \multicolumn{3}{|c|}{ Групи тварин } \\
\cline { 1 - 2 } & Контрольна & Дослідна 1 & Дослідна 2 \\
\hline П’ята & \multirow{3}{*}{$6,46 \pm 0,149$} & $5,67 \pm 0,124^{* *}$ & $5,91 \pm 0,119^{*}$ \\
\hline Десята & & $4,98 \pm 0,099^{* * *}$ & $5,98 \pm 0,112^{*}$ \\
\cline { 1 - 2 } Двадцята & & $4,75 \pm 0,123^{* * *}$ & $5,92 \pm 0,085^{*}$ \\
\cline { 1 - 2 } Двадцять п’ята & & $5,04 \pm 0,111^{* * *}$ & $6,15 \pm 0,123$ \\
\cline { 1 - 2 } & & $5,11 \pm 0,097 * *$ & $6,39 \pm 0,130$ \\
\hline
\end{tabular}

Примітка: у цій і наступних таблицях: тупінь вірогідності: $-\mathrm{p}<0,05 ; * *-\mathrm{p}<0,025 ; * * *-\mathrm{p}<0,001$

При згодовуванні кормової добавки «Бутаселмевіт-плюс» кількість еритроцитів у крові другої дослідної групи щурів була вищою за показники першої дослідної групи, однак контрольних величин вона досягала лише на 30-ту добу досліду. Найнижчою кількість еритроцитів у крові дослідної групи Д 2 була на 5-ту добу досліду, де відповідно вона становила 
5,91士0,119 Т/л. На 20-ту добу досліду кількість еритроцитів у крові другої дослідної групи була вищою за досліду першу, однак порівняно з контрольною групо була нижчою на 8,4%, відповідно.

У хворих щурів дослідної групи Д 1 знижується, порівняно з показниками інтактних тварин, рівень гемоглобіну. Так, на 10-ту добу досліду рівень гемоглобіну у їх крові знизився на 5,6\%, тоді як на 20-ту добу - на 8,7\% відносно показників контрольної групи щурів. На 25 і 30-ту доби досліду рівень гемоглобіну дещо зріс порівняно з попередньою добою, однак порівняно з контрольною групою залишався на низькому рівні (табл. 2).

Рівень гемоглобіну у крові щурів за умов отрусння тетрахлорметаном та за дії кормової добавки «Бутаселмевіт-плюс», г/л $(\mathrm{M} \pm \mathbf{m} ; \mathrm{n}=\mathbf{2 0})$

\begin{tabular}{|c|c|c|c|}
\hline \multirow{2}{*}{ Доба досліджень } & \multicolumn{3}{|c|}{ Групи тварин } \\
\hline & Контрольна & Дослідна 1 & Дослідна 2 \\
\hline П'ята & \multirow{5}{*}{$148,8 \pm 1,57$} & $150,2 \pm 1,85$ & $149,8 \pm 1,42$ \\
\hline Десята & & $140,4 \pm 2,05^{*}$ & $148,2 \pm 1,76$ \\
\hline Двадцята & & $135,8 \pm 0,97 * * *$ & $153,4 \pm 1,24$ \\
\hline Двадцять п’ята & & $140,7 \pm 1,11^{* *}$ & $150,7 \pm 1,59$ \\
\hline Тридцята & & $141,6 \pm 2,17^{*}$ & $150,4 \pm 1,24$ \\
\hline
\end{tabular}

Зниження еритроцитів у крові дослідної групи щурів також пов’язують 3 тим, що вони $\epsilon$ особливо чутливими до дії оксидаційного стресу, який розвивається внаслідок введення тетрахлорметану. На основі показників кількості еритроцитів та вмісту гемоглобіну крові не можна об'єктивно оцінити гемопоетичну функцію кісткового мозку щурів за розвитку оксидаційного стресу, саме тому визначають величини індексів червоної крові: середній об'єм одного еритроцита (MCV), збільшення величини якого (макроцитоз) є показником помірного еритроцитозу.

За збільшення середнього об’єму еритроцитів (табл. 3) і вмісту гемоглобіну в еритроциті (табл. 4) відзначена тенденція до зменшення середньої концентрації гемоглобіну в еритроциті (табл. 5). Дані зміни пов’язанні з дією тетрахлорметану на початкових стадіях розвитку оксидаційного стресу і ймовірно, дані зміни носять компенсаторний характер.

Таблиия 3

Об'см еритроцита у крові щурів за умов отруєння тетрахлорметаном та за дії кормової добавки «Бутаселмевіт-плюс», мкм ${ }^{3}(\mathrm{M} \pm \mathrm{m} ; \mathbf{n}=\mathbf{2 0})$

\begin{tabular}{|c|c|c|c|}
\hline \multirow{2}{*}{ Доба досліджень } & \multicolumn{3}{|c|}{ Групи тварин } \\
\hline & Контрольна & Дослідна 1 & Дослідна 2 \\
\hline П'ята & \multirow{5}{*}{$43,5 \pm 1,15$} & $51,9 \pm 1,18^{* *}$ & $49,1 \pm 1,12^{*}$ \\
\hline Десята & & $61,6 \pm 1,22 * * *$ & $50,0 \pm 1,18 * *$ \\
\hline Двадцята & & $66,5 \pm 1,18 * * *$ & $49,3 \pm 1,20 *$ \\
\hline Двадцять п’ята & & $62,1 \pm 1,15 * * *$ & $47,0 \pm 1,11$ \\
\hline Тридцята & & $60,5 \pm 1,20 * * *$ & $44,8 \pm 1,13$ \\
\hline
\end{tabular}

Маса гемоглобіну в еритроциті у крові щурів за умов отрусння тетрахлорметаном

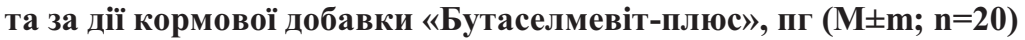

\begin{tabular}{|c|c|c|c|}
\hline \multirow{2}{*}{ Доба досліджень } & \multicolumn{3}{|c|}{ Групи тварин } \\
\hline & Контрольна & Дослідна 1 & Дослідна 2 \\
\hline П'ята & \multirow{5}{*}{$23,03 \pm 1,50$} & $26,49 \pm 1,32$ & $25,35 \pm 1,25$ \\
\hline Десята & & $28,19 \pm 1,26^{*}$ & $24,78 \pm 1,40$ \\
\hline Двадцята & & $28,59 \pm 1,29^{*}$ & $25,91 \pm 1,16$ \\
\hline Двадцять п’ята & & $27,92 \pm 1,32 *$ & $24,50 \pm 1,41$ \\
\hline Тридцята & & $27,71 \pm 1,34$ & $23,54 \pm 1,38$ \\
\hline
\end{tabular}


На 10-ту добу досліду у крові щурів дослідної групи Д1 встановлено збільшення гематокритної величини до $30,7 \pm 1,45$ л/л, тоді як у контрольної групи даний показник становив $28,1 \pm 0,68$ л/л. Згодовування кормової добавки «Бутаселмевіт-плюс» щурам дослідної

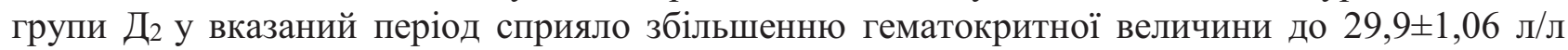
(табл. 6).

Таблиия 5

Концентрація гемоглобіну в еритроциті у крові щурів за умов отрусння тетрахлорметаном та за дії кормової добавки «Бутаселмевіт-плюс», \% $(\mathrm{M} \pm \mathrm{m} ; \mathrm{n}=\mathbf{2 0})$

\begin{tabular}{|l|c|c|c|}
\hline \multirow{2}{*}{ Доба досліджень } & & \multicolumn{3}{|c|}{ Групи тварин } \\
\cline { 1 - 3 } & Контрольна & Дослідна 1 & Дослідна 2 \\
\hline П'ята & \multirow{3}{*}{$53,00 \pm 1,34$} & $51,09 \pm 1,39$ & $51,66 \pm 1,29$ \\
\hline Десята & $45,73 \pm 1,32^{* *}$ & $49,57 \pm 1,30$ \\
\cline { 1 - 1 } Двадцята & $42,97 \pm 1,28^{* *}$ & $52,53 \pm 1,30$ \\
\cline { 1 - 1 } Двадцять п'ята & & $44,95 \pm 1,33^{* *}$ & $52,15 \pm 1,34$ \\
\cline { 1 - 1 } & & $45,83 \pm 1,37^{* *}$ & $52,59 \pm 1,36$ \\
\hline
\end{tabular}

Збільшення кількості лейкоцитів у крові щурів дослідних груп після введення їм тетрахлорметану є результатом розвитку в організмі запальних процесів.

Таблиця 6

Величина гематокриту у крові щурів за умов отруєння тетрахлорметаном та за дії кормової добавки «Бутаселмевіт-плюс», л/л (M \pm m; n=20)

\begin{tabular}{|c|c|c|c|}
\hline \multirow{2}{*}{ Доба досліджень } & \multicolumn{3}{|c|}{ Групи тварин } \\
\hline & Контрольна & Дослідна 1 & Дослідна 2 \\
\hline П'ята & \multirow{5}{*}{$28,1 \pm 0,68$} & $29,4 \pm 1,24$ & $29,0 \pm 1,10$ \\
\hline Десята & & $30,7 \pm 1,45$ & $29,9 \pm 1,06$ \\
\hline Двадцята & & $31,6 \pm 1,34$ & $29,2 \pm 0,98$ \\
\hline Двадцять п’ята & & $31,3 \pm 1,30$ & $28,9 \pm 0,91$ \\
\hline Тридцята & & $30,9 \pm 1,46$ & $28,6 \pm 1,01$ \\
\hline
\end{tabular}

Встановлено, що у крові щурів першої дослідної групи кількість лейкоцитів на 10-ту добу досліду зросла на 24,9\%, тоді як на 20-ту добу - на 34,0\% порівняно з інтактними щурами. У крові щурів дослідної групи Д2 кількість лейкоцитів у вказані періоди досліду була вищою на 9,6 і 7,6\%. На 30-ту добу досліду кількість показника, що досліджувався, у крові другої дослідної групи доходив до фізіологічних величин (табл. 7).

Таблиця 7

Кількість лейкоцитів у крові щурів за умов отруєння тетрахлорметаном та за дії кормової добавки «Бутаселмевіт-плюс», Г/л (M $\pm \mathbf{m} ; \mathbf{n = 2 0})$

\begin{tabular}{|c|c|c|c|}
\hline \multirow{2}{*}{ Доба досліджень } & \multicolumn{3}{|c|}{ Групи тварин } \\
\hline & Контрольна & Дослідна 1 & Дослідна 2 \\
\hline П’ята & \multirow{5}{*}{$9,34 \pm 0,760$} & $10,74 \pm 0,731$ & $10,13 \pm 0,820$ \\
\hline Десята & & $11,67 \pm 1,221$ & $10,24 \pm 1,106$ \\
\hline Двадцята & & $12,52 \pm 1,357^{*}$ & $10,05 \pm 1,310$ \\
\hline Двадцять п’ята & & $12,10 \pm 1,621^{*}$ & $9,87 \pm 1,754$ \\
\hline Тридцята & & $11,67 \pm 0,987$ & $9,45 \pm 1,052$ \\
\hline
\end{tabular}

Відновлення гемопоетичної функції кісткового мозку щурів за інтоксикації тетрахлорметаном, відбувається завдяки тому, що кормова добавка «Бутаселмевіт-плюс» містить у своєму складі плоди розторопші плямистої, у яких є високий рівень вітамінів А і К, та мікроелементів, а саме: Купруму, Феруму та Кобальту, що беруть безпосередню участь в гемопоезі. 


\title{
В И С Н О В К И
}

За умов інтоксикації тетрахлорметаном у щурів порушується гемопоетична функція кісткового мозку, що проявляється зменшенням кількості еритроцитів на 26,5\%, вмісту гемоглобіну на 8,7\%, концентрації гемоглобіну в еритроциті на 18,9\%, збільшенням маси гемоглобіну в еритроциті на 24,1\%, об’ єму еритроцита на 53,9\%.

При застосуванні кормової добавки «Бутаселмевіт-плюс» щурам, за умов оксидаційного стресу протягом досліджень, у крові наступає нормалізація активності гематологічних показників, а саме на 25 і 30-ту доби в межах фізіологічних величин були показники кількості еритроцитів, вмісту гемоглобіну, кількості лейкоцитів та індекси червоної крові порівняно 3 контролем, що вказує на відновлення гемопоетичної функції кісткового мозку.

Перспективи досліджень. У подальшому планується вивчити вплив кормової добавки «Бутаселмевіт-плюс» на морфологічні показники поросят при відлученні від свиноматки.

\section{MORPHOLOGICAL INDICATORS OF RAT'S BLOOD UNDER CONDITIONS OF OXIDATION STRESS AND FOR ACTION OF THE FOOD ADDITIVES «BUTASELMEVIT-PLUS»}

\author{
T. V. Martyshchuk ${ }^{1}$, B. V. Gutyj ${ }^{2}$
}

${ }^{1}$ Institute of Animal Biology NAAS, 38, V. Stysa str, Lviv, 79034, Ukraine

${ }^{2}$ Lviv National University of Veterinary Medicine and Biotechnologies named after S. Z. Gzhytskyi 50, Pekarska str., Lviv, 79010, Ukraine

\section{S U M M A R Y}

Free radical oxidation plays an extremely important role in the development of many pathological processes. Poisoning of experimental animals with tetrachloromethane according to the morphological picture and biochemical changes close to the acute liver lesions of different etiologies in humans and animals. That is why in our work the classic model of damage of hepatocyte subcellular membranes has been used and the development of oxidation stress based on the use of tetrachloromethane. The purpose of the work was to study the morphological parameters of blood in rats under the conditions of oxidative stress and the action of the feed additive «Butaselem-plus». The studies were conducted on white, sexually-mature, young male rats of the Wistar line with a body weight of 180-200 g, which were kept on the standard diet of the institute vivarium of the State Scientific-Research Control Institute of Veterinary Preparations and Feed Additives. Animals were divided into three groups of 20 animals in each: 1st group (K) intact animals; Group 2 (D1) - rat, afflicted with tetrachloromethane; Group 3 (D2) - rat, lesions tetrachloromethane and which were used as feed additive «Butaselem-plus». Experimental intoxication in animals was carried out by twotime (after $48 \mathrm{~h}$ ) of intravenous administration of tetrachloromethane in a dose of $0.1 \mathrm{ml}$ per $100 \mathrm{~g}$ of body weight of the rat in the form of $50 \%$ of the oil solution. For the experimental group D2 for experimental toxicosis for 30 days fed a feed supplement «Butaselmeib plus» in a dose of $0.1 \mathrm{~g}$ per $100 \mathrm{~g}$ of body weight with food.

It was established that under conditions of intoxication with tetrachloromethane in rats, hematopoietic function of bone marrow is violated, which is manifested by a decrease in the number of erythrocytes by $26.5 \%$, hemoglobin content by $8.7 \%$, hemoglobin concentration in erythrocyte by $18.9 \%$, increased weight of hemoglobin in erythrocyte by $24.1 \%$, erythrocyte volume by $53.9 \%$. In the application of the feed supplement «Butaselmevit Plus» to rats, under conditions of oxidative stress during research, the normalization of the activity of hematological parameters occurs in the blood, namely on the 25 th and 30th days within the limits of physiological values were indicators of 
the number of erythrocytes, hemoglobin content, the number of leukocytes and indices of red blood compared with the control, indicating the restoration of hematopoietic function of the bone marrow.

Keywords: OXIDATIVE STRESS, RATS, BUTASELMEVIT-PLUS, BLOOD, MILK THUSTLES.

\title{
МОРФОЛОГИЧЕСКИЕ ПОКАЗАТЕЛИ КРОВИ КРЫС ПРИ ОКСИДАТИВНОМ СТРЕССЕ И ПОД ДЕЙСТВИЕМ КОРМОВОЙ ДОБАВКИ «БУТАСЕЛМЕВИТ- ПЛЮС»
}

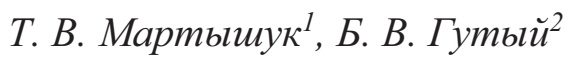 \\ ${ }^{1}$ Институт биологии животных НААН, \\ ул. В. Стуса, 38, 79000, г. Львов, Украина \\ 2Львовский национальный университет ветеринарной медицины и биотехнологий \\ имени С. 3. Гжицкого, \\ ул. Пекарская, 50, г. Львов, 79010, Украина

\section{А Н Н О Т А ЦИ Я}

Свободнорадикальное окисление играет чрезвычайно важную роль в развитии многих патологических процессов. Отравление экспериментальных животных тетрахлорметаном по морфологической картине и биохимическими изменениями близко к острым поражениям печени различной этиологии у человека и животных. Именно поэтому в нашей работе использовано классическую модель повреждения субклеточных мембран гепатоцитов и развития оксидативного стресса на основе применения тетрахлорметана. Целью работы было изучить морфологические показатели крови крыс в условиях оксидативного стресса и за действия кормовой добавки «Бутаселмевит-плюс». Исследования проводили на белых половозрелых молодых крысах-самцах линии Вистар массой тела 180-200 г, содержавшихся на стандартном рационе вивария Государственного научно-исследовательского контрольного института ветеринарных препаратов и кормовых добавок. Животные были разделены на три группы по 20 животных в каждой: 1-я группа (К) интактные животные; 2-я группа (O1) крысы при интоксикации тетрахлорметаном; 3-я группа $(\mathrm{O} 2)$ - крысы при интоксикации тетрахлорметаном и которым применяли кормовую добавку «Бутаселмевит-плюс». Экспериментальную интоксикацию у животных проводили путем двукратного (через 48 ч) внутрижелудочного введения тетрахлорметана в дозе 0,1 мл на 100 г массы тела крысы в виде 50 \% масляного раствора. Опытной группе О2 при экспериментальном токсикозе в течение 30 суток скармливали кормовую добавку «Бутаселмевит-плюс» в дозе 0,1 г на 100 г массы тела вместе с кормом.

Установлено, что в условиях интоксикации тетрахлорметаном у крыс нарушается гемопоэтическая функция костного мозга, что проявляется уменьшением количества эритроцитов на 26,5 \%, содержания гемоглобина на 8,7 \%, концентрации гемоглобина в эритроците на 18,9\%, увеличением массы гемоглобина в эритроците на $24,1 \%$, объема эритроцита на 53,9\%. При применении кормовой добавки «Бутаселмевит-плюс» крысам, в условиях оксидативного стресса в течение исследований, в крови наступает нормализация активности гематологических показателей, а именно на 25 и 30-ю сутки в пределах физиологических величин были показатели количества эритроцитов, содержания гемоглобина, количества лейкоцитов и индексы красной крови по сравнению с контролем, что указывает на восстановление гемопоэтической функции костного мозга.

Ключевые слова: ОКСИДАТИВНЫЙ СТРЕСС, КРЫСЫ, БУТАСЕЛМЕВИТ-ПЛЮС, КРОВЬ, РАСТОРОПША ПЯТНИСТАЯ. 
1. Effects of indoleamine 2,3-dioxygenases in carbon tetrachloride-induced hepatitis model of rats / Li D., Cai H., Hou M., Fu D., Luo Q., Yuan X., Lv M., Zhang X., Cong X., \& Lv Z. // Cell Biochem Funct. - 2012. - Vol. 30, № 4. - P. 309-314.

2. Гутий Б. В. Вплив хлориду кадмію на інтенсивність процесів перекисного окиснення ліпідів та стан системи антиоксидантного захисту організму щурів / Б. В. Гутий // Вісник Сумського національного аграрного університету. - Суми, 2012. Вип.7(31) - С. 31-34.

3. Гутый Б. В. Особенности функционирования системы антиоксидантной защиты организма крыс при кадмиевом токсикозе / Б. В. Гутый // Ученые записки учреждения образования «Витебская ордена «Знак Почета» государственная академия ветеринарной медицины» : научно-практический журнал. - Витебск, 2016. - Т. 52, вып. 2. - С. 24-28.

4. Абрагамович O. О. Процеси ліпідної пероксидації при хронічних ураженнях печінки / О. О. Абрагамович, О. І. Грабовська, О. І. Терлецька // Медична хімія. - 2000. - Т. 2, № 1. - C. 5-8.

5. Hariv M. I. Influence of the liposomal preparation Butaintervite on protein synthesis function in the livers of rats under the influence of carbon tetrachloride poisoning / M. I. Hariv, B. V. Gutyj // Visnyk of Dnipropetrovsk University. Biology, medicine. - 2016. - Tом 7, № 2. - P. 123126.

6. Influence of cadmium loading on the state of the antioxidant system in the organism of bulls / B. V. Gutyj, S. D. Murs'ka, D. F. Gufrij et al. // Visnyk of Dnipropetrovsk University. Biology, ecology. - 2016. Том 24, № 1. - P. 96-102.

7. Вплив препарату «Метісевіт» на активність ензимної та неензимної ланки антиоксидантного захисту організму бугайців за умов кадмієвого навантаження / Гутий Б. В., Лавришин Ю. Ю., Бінкевич В. Я. та ін. // Науковий вісник Львівського національного університету ветеринарної медицини та біотехнологій імені С.3. Гжицького. -2016. - т 18, № 2 (66). - C. 52-58.

8. Hematological indices of rat organisms under conditions of oxidative stress and liposomal preparation action / M. Khariv, B. Gutyj, V. Butsyak, I. Khariv // Biological Bulletin of Bogdan Chmelnitskiy Melitopol State Pedagogical University. -2016. Vol. 6(1). - P. 276-289.

9. Martyshuk T. V. Level of lipid peroxidation products in the blood of rats under the influence of oxidative stress and under the action of liposomal preparation of "Butaselmevit" / T. V. Martyshuk, B. V. Gutyj, O. I. Vishchur// Biological Bulletin of Bogdan Chmelnitskiy Melitopol State Pedagogical University. - 2016. - Vol. 6 (2). - P. 22-27.

10. Вплив антиоксидантів на активність ензимів глутатіонової системи антиоксидантного захисту організму бичків за гострого нітратно-нітритного токсикозу / В. О. Губерук, Б. В. Гутий, Д. Ф. Гуфрій та ін. // Науковий вісник Львівського національного університету ветеринарної медицини та біотехнологій імені С.3. Гжицького. - 2017. - т 19, № 77. - C. 220-224.

11. Лавришин Ю. Ю. Біологічне значення системи антиоксидантного захисту організму тварин / Ю. Ю. Лавришин, І. С. Вархоляк, Т. В. Мартишук та ін. // Науковий вісник Львівського національного університету ветеринарної медицини та біотехнологій імені С. 3. Гжицького. Серія: : Ветеринарні науки. - 2016. - Т. 18, № 2. - С. 100-111.

12. Khariv M. Activity of the T- and B-system of the cell immunity of animals under conditions of oxidation stress and effects of the liposomal drug / M. Khariv, B. Gutyj, N. Ohorodnyk et al. // Ukrainian Journal of Ecology. - 2017. - Vol. 7(4). - P. 536-541.

13. Lee J. Y. The preventive inhibition of chondroitin sulfate against the CCI4-induced oxidative stress of subcellular level / J. Y Lee, J. H. Lee, H. J. Kim [et al.) // Arch.Pharm.Res. - 2004. - Vol. 27, №3. - P. 340-345. 
14. Скрипник I. M. Гепатопротеторні засоби в сучасній гепатології // Consilium Medicum Ukraina. - 2007. - №1(5). - C. 11-15.

15. Saba A. B., Oyagbemi A. A., Azeez O. I. Amelioration of carbon tetrachloride-induced hepatotoxicity and haemotoxicity by aqueous leaf extract of Cnidoscolus aconitifolius in rats. Nig. J. Physiol. Sci. - 2010 - Vol. 25. - P. 139-147.

16. Антоняк $Г$. Л. Утворення активних форм кисню та система антиоксидантного захисту в організмі тварин / Г. Л. Антоняк, Н. О. Бабич, Л. І. Сологуб // Біологія тварин. -2000. - Т. 2, № 2.- С. 34-43.

17. Бєленічев I. Ф. Антиоксидантна система захисту організму (огляд) / І. Ф. Бєленічев, Є. Л. Левицький, С. І. Коваленко // Современные проблемы токсикологии. - 2002. - № 3. - С. 29-31.

18. Лабораторні методи досліджень у біології, тваринництві та ветеринарній медицині : довідник / В. В. Влізло, Р. С. Федорук, І. Б. Ратич та ін.; за ред. В. В. Влізла. Львів : Сполом, 2012. $764 \mathrm{c}$.

\section{References}

1. Li, D., Cai, H., Hou, M., Fu, D., Luo, Q., Yuan, X., Lv, M., Zhang, X., Cong, X., \& Lv, Z. (2012) Effects of indoleamine 2,3-dioxygenases in carbon tetrachloride-induced hepatitis model of rats. Cell Biochem Funct, 30(4), 309-314. doi: 10.1002/cbf.2803.

2. Gutiy, B. V. (2012). Vplyv hlorydu kadmiyu na intensivnist protsesiv perekisnogo okysnennya lipidiv ta stan sistemy antyoksydantnogo zahystu organizmu shchuriv. Visnyk Sumskogo natsionalnogo agrarnogo universitetu, 7(31), 31-34 (in Ukrainian).

3. Gutyj, B. V. (2016). Osobennosti funkcionirovanija sistemy antioksidantnoj zashhity organizma krys pri kadmievom toksikoze. Nauchno-prakticheskij zhurnal. Uchenye Zapiski, 52(2), 24-28 (in Russian).

4. Abragamovich, O. O., Grabovska, O. I., \& Terletska, O. I. (2000). Protsesy lipidnoyi peroksidatsiyi pry hronichnyh urazhennyah pechinky. Medichna himiya, 2(1), 5-8 (in Ukrainian).

5. Hariv, M. I., \& Gutyj, B. V. (2016). Influence of the liposomal preparation Butaintervite on protein synthesis function in the livers of rats under the influence of carbon tetrachloride poisoning. Visnyk of Dnipropetrovsk University. Biology, medicine, 7(2), 123-126. doi: $10.15421 / 021622$.

6. Gutyj, B. V., Murs'ka, S. D., Gufrij, D. F., Hariv, I. I., Levkivs'ka, N. D., Nazaruk, N. V., Gajdjuk, M. B., Pryjma, O. B., Bilyk, O. Ja., \& Guta, Z. A. (2016). Influence of cadmium loading on the state of the antioxidant system in the organism of bulls. Visnyk of Dnipropetrovsk University. Biology, ecology, 24(1), 96-102. doi: 10.15421/011611.

7. Gutyj, B., Lavryshyn, Y., Binkevych, V., Binkevych, O., Paladischuk, O., Strons'kyj, J., \& Hariv, I. (2016). Influence of «Metisevit» on the activity of enzyme and nonenzyme link of antioxidant protection under the bull's body cadmium loading. Scientific Messenger LNUVMBT named after S.Z. Gzhytskyj, 18, 2(66), 52-58. doi: 10.15421/nvlvet6612. (in Ukrainian)

8. Khariv, M., Gutyj, B., Butsyak, V., \& Khariv, I. (2016). Hematological indices of rat organisms under conditions of oxidative stress and liposomal preparation action. Biological Bulletin of Bogdan Chmelnitskiy Melitopol State Pedagogical University, 6(1), 276-289. doi: 10.15421/201615. (in Ukrainian)

9. Martyshuk, T. V., Gutyj, B. V., \& Vishchur, O. I. (2016). Level of lipid peroxidation products in the blood of rats under the influence of oxidative stress and under the action of liposomal preparation of «Butaselmevit», Biological Bulletin of Bogdan Chmelnitskiy Melitopol State Pedagogical University, 6(2), 22-27. doi: 10.15421/201631.

10. Huberuk, V., Gutyj, B., Gufriy, D., Binkevych, V., Hariv, I., Binkevych, O., \& Salata, R. (2017). Impact of antioxidants on enzym activities of glutatione system of bulls bodies antioxidant 
defense under acute nitrate and nitrite toxicity. Scientific Messenger LNUVMBT named after S.Z. Gzhytskyj, 19(77), 220-224.

11. Lavryshyn, Y. Y., Varkholyak, I. S., Martyschuk, T. V., Guta, Z. A., Ivankiv, L. B., Paladischuk, O. R., Murska, S. D., Gutyj, B. V., \& Gufriy, D. F. (2016). The biological significance of the antioxidant defense system of animals body. Scientific Messenger LNUVMBT named after S.Z. Gzhytskyj, 18, 2(66), 100-111. doi: 10.15421/nvlvet6622.

12. Khariv, M., Gutyj, B., Ohorodnyk, N., Vishchur, O., Khariv, I., Solovodzinska, I., Mudrak, D., Grymak, C., \& Bodnar, P. (2017). Activity of the T- and B-system of the cell immunity of animals under conditions of oxidation stress and effects of the liposomal drug. Ukrainian Journal of Ecology, 7(4), 536-541. doi: 10.15421/2017_157.

13. Lee, J. Y., Lee, J. H., \& Kim, H. J. (2004). The preventive inhibition of chondroitin sulfate against the CCI4-induced oxidative stress of subcellular level. Arch. Pharm. Res., 27(3), 340-345.

14. Skry`pny`k, I. M. (2007). Gepatoprotetorni zasoby`v suchasnij gepatologiyi. Consilium Medicumllkraina, 1(5), 11-15 (in Ukrainian).

15. Saba, A. B., Oyagbemi, A. A., \& Azeez, O. I. (2010). Amelioration of carbon tetrachloride-induced hepatotoxicity and haemotoxicity by aqueous leaf extract of Cnidoscolus aconitifolius in rats. Nig. J. Physiol. Sci., 25(2), 139-147.

16. Antonyak, G. L., Babich, N. O., \& Sologub, L. I. (2000). Utvorennya aktivnih form kisnyu ta sistema antioksidantnogo zahistu v organizmi tvarin. Biologiya tvaryn, 2(2), 34-43 (in Ukrainian).

17. Belenichev, I. F. Levitskiy, E. L., \& Kovalenko, S. I. (2002) Antioksidantna sistema zahistu organizmu (oglyad). Sovremennye problemy toksikologii, 3, 29-31 (in Russian).

18. Vlizlo, V. V., Fedoruk, R. S., \& Ratych, I. B. (2012). Laboratory methods of investigation in biology, stock-breeding and veterinary. A reference book. Ed. by VV Vlizlo. Lviv: Spolom (in Ukrainian).

Рецензент - М. І. Жила, д. вет. н., доцент, ДНДКІ ветпрепаратів та кормових добавок. 